\section{Industrial Relations Bargaining in the Retail Non-food Sector: 1991-1992}

\section{Janet Hector, Jon Henning, and Mary Hubble*}

This report looks at bargaining in an industry with a significant level of small busines activity, the retail non-food sector, in light of the deregulation of the economy and in particular, the Employment Contracts Act. It also looks at the effect of these changes in employees at the lower end of the labour market in this sector. The study finds that in on context of a stagnant market the Act enabled in this sector. The study finds that, in the flexibility in relation to hours and penal rates and has been to pursue long held goals of flexibility in relation to hours and penal rates and has been associated with the reduction of union influence in small firms. The general effect on employees in the sector is difficult to assess but it is probable that conditions have deteriorated for some workers in some parts of the sector.

\section{Introduction}

This study of industrial relations bargaining in the retail non-food sector is based on research undertaken during 1991 and 1992 which was primarily motivated by two concerns. The first concern was to look at what seemed to be an increasingly diversified industrial relations environment from the perspective of an industry in which there was significant small business activity. Underlying this interest was our perception there was significant relations were still concentrated on the activity of lare perception that reports of industrial high profile unions. The second conves deregulation, particularly the impact of the Empast of increased lower end of the labour cow clear interest here was the effect on these workers of a labour market which involved less collective bargaining and was operating under conditions of historically high
unemployment.

These main interests coincided in the retail non-food sector. The industry is traditionally seen as comprising predominantly small businesses and employing often low-skilled low-
paid workers, features which are generally confirmed by the statistical profile of the retail sector and related industries (these are "wholesale and by the statistical profile of the retail which are classified as major division "wholesale and retail trade, restaurants and hotels" which are classified as major division six of the New Zealand Standard Industria Classification used by the Department of Statistics and referred to in the remainder paper as NZSIC 6). At the beginning of 1991, for example, over 50 percent of employees in the retail sector as a whole worked in enterprises employing less than 10 staff, compared to 28 percent for all industries. Average hourly ordinary time earnings in NZSIC 6 industries in February 1992 were more than 15 percent lower than average rates over the whole economy. Often associated with low-pay and low-skill levels are high levels of parttime work. At the end of 1991, 37 percent of all positions in NZSIC 6 industries were parttime compared to 26 percent over the whole economy. (Statistics used in this paper are drawn generally from the Department of Statistics' publications Business Activity Statistics 1991 and Key Statistics, or from its INFOS database.)

The gender breakdown of these pay and part-time statistics also confirms that a significant majority of the poorly paid and low-skilled employees in NZSIC 6 industries are female. While the number of male and female workers were almost equal in NZSIC 6 industries (the same industries were 78 percent of male earnings 1992 (compared to 82 percent for all sectors). Women were also twice as likely to be in part-time employment than men. Fifty-one per cent of the jobs filled by women in NZSIC 6 industries were part-time compared to 23.5 percent for men. The comparable figures for all sectors are 40 percent and 13.5 percent. The breakdown supports Brosnan's observation that males generally dominate in the primary labour market of the retail sector, for example, management and buying, whereas women make up a predominant part of the secondary labour market in occupations such as shop assistants and checkout operators in supermarkets (Brosnan, 1991: 20, 32)

In general, this study should help to flesh out the picture of bargaining processes and outcomes under the Employment Contracts Act which is being developed by various researchers. Boxall (Boxall, 1993) has reviewed management strategies and identified a series of employer strategies which can be associated with those identified by Heylen Teesdale Meuli (Heylen Teesdale Meuli, 1992). McAndrew's study of the process of developing employment contracts confirms some of these patterns, including in particular developing employment contracts confirms some of these patterns, including in particular
the continuation of many workplaces in a state of 'limbo' on pre-existing award conditions or no formal contract, and the assertive behaviour of many employers in workplaces where unions have no active role (McAndrew, 1993). Harbridge has documented the changing structures and outcomes of bargaining on an economy wide basis, noting the variety of the outcomes which have b working time and penal rates in certain sectors (Harbridge, 1993). The position of women under the Employment Contracts Act has also been explored, for example, the position of those in the peripheral workforce and in the service sector (Sayers, 1991), and the limited wage increases achieved in contracts covering predominantly female workers (Harbridge and Hammond, 1993). The patterns found in the retail sector by this survey exemplify some of these conclusions and show how different patterns exist within a single sector.

The following discussion of industrial relations in the retail non-food sector is presented in three parts. The first is an outline of the general environmental influences affecting industrial relations in the industry up to 1992 . The second, an overview of the major features of bargaining within the sector, is presented mainly in the context of a description of bargaining which has general application to the whole of the retail sector. The third part of the paper is a complementary report on a case study of specific segments of the retail non-food sector. The overall focus of the paper is to describe bargaining structures, bargaining objectives, and outcomes in the retail non-food sector and how they were being 
Act.

Major sources for the outline of environmental factors and overview of bargaining were interviews with officials in the New Zealand Distribution Workers Federation and the Retail and Wholesale Merchants Federation, conducted on a confidential basis, published sources.

The sources for the case study were face-to-face interviews with 58 retailers, mainly in three segments of the industry: appliances, women's fashions, and book sellers and stationers, chosen to give a balance of employment patterns and types of outlet. The study was carried out in three different locations: Wellington, Ashburton, and Wanganui, to cover provincial as well as metropolitan retail environments and to include a South Island cover All retailers within the defined category in each region were identified from the centre. directory. Almost all those contacted in Ashburton a questionnaire covering the environment the range and in the range and incidence of ordinary and penal pay rates, form of contracts and process of negotiation. In Wellington all were contacted by telephone and asked the number of employees and whether temporary workers were employed, in order to provide information on which to base a further selection, in view of limited resources. A significant number had no staff, and a second significant group did not was then made from the remainder on the bosis of size ind type of busioction interviewed as in Wanganui and Ashburton. Fousiness, an in Ashburton, 29 in Wellingto and Ashburton. Fourteen retailers were finally interviewed in Ashburton, 29 in Wellington and 16 in Wanganui. Chain stores were represented by on interview in all cases, either the head office or a single outlet. This meant that a number of outlets in the survey categories were not interviewed, particularly in Wanganui, and that there was a lower proportion of mall outlets involved than would otherwise case. To balance the representation of appliance chains, the head office of such a chen the interviewed in Christchurch.

The results of the case study are presented as indicative, not representative, of current industrial relations in the sector. It may also be noted that only employers were interviewed in the case study. The survey was confined to employers because of the difficulties of mounting a parallel employee survey with a suitable sample, obtaining the to employees, and in relating employee responses to information obtained from the employer survey.

\section{Environmental factors}

The retail non-food sector, like all sectors of the economy, is subject to a number of environmental factors which influence business outcomes and bargaining behaviour. It is not possible to provide a definitive assessment of the extent to which particular factors have influenced the firms studied. The following, however, outlines three factors which are likely to have influenced the sector in general.
The retail sector has been generally depressed in recent years with generally low sales throughout the period from 1984 to the survey date, with minor fluctuations. Some growth occurred in the three quarters to March 1992 and this has generally continued since. Overall, however, this growth has been modest and from a low base.

Low levels of demand in the retail industry from 1984 also coincided with deregulation of the economy. Deregulation, particularly in relation to changes to tariff controls and currency regulations, directly affected the industry in two main ways: firstly, in attracting overseas firms such as KMart into the industry; and, secondly, allowing greater importing of cheaper goods from overseas, thus providing severe competition on the basis of product price (Brosnan, ibid: 15). The increase in competition in the industry was not matched by an increase in sales and placed pressure on profit margins and cost structures.

Another important influence on the retail non-food sector was the repeal of most of the provisions of the Shop Trading Hours Act in 1990, which provided retailers with the opportunity to open longer hours. Opportunity to open, however, also provided the basis for increased pressure on retailers to extend hours, particularly in metropolitan centres. Pressure came from a number of sources: a perceived need to maintain competitiveness with rival retailers prepared to extend hours; the development of malls and pressure from mall owners concerned to maximise utilisation of their premises and increase rent potential; and increased pressure from consumers for whom weekends was a more convenient time to shop and/or for whom shopping as a leisure activity had grown in popularity. Longer hours, regardless or the reasons for their extension, also probably increased the pressure on some enterprises to control costs. The number of activity units in the sector fluctuated, rather than fell, from 1987 to 1991 and sales, as discussed, did not increase. Thus average sales per unit did not rise to compensate for increases in overheads, for example, labour, heating, lighting.

The third major influence was the Employment Contracts Act. The Act changed the legal framework in two areas. Firstly, it removed the effective requirement for most employees to belong to a union. And secondly, it allowed the parties to negotiate individual or collective contracts and made it more difficult to negotiate multi-employer contracts. In this environment, employers could, on an individual basis, pursue particular changes where they previously felt constrained by the award structure. Movement on penal rate reductions had been impossible to achieve under the Retail Non-food Award, for example, because of been impossible to achieve under the Retail Non-food Award, for example, because of
disagreement between employers as to the best strategy for achieving reductions, and this had contributed to the failure to renegotiate the document in 1990. The Act enabled employers to approach the issue in different ways, and change consequently occurred in a considerable number of instances.

\section{Bargaining: an overview}

Structure

Up to the passing of the Employment Contracts Act, the focus of formal bargaining in the retail sector was the negotiation of two major awards, the New Zealand Retail Grocery and 
Supermarket Employees Award and the Retail (Non-Food) Employees Award, which provided blanket coverage over much of the industry. Some specific segments of the sector had separate awards, for example, chemists, butchers, fish shops. Only a small number of enterprises such as duty free stores, some supermarkets, and KMart, had their own separate registered documents. The Retail (Non-Food) Award expired and was not renewed prior to the Employment Contracts Act coming into force. The Grocery and Supermarket Award to the Employment Contar expired on 3 December 1991. The common negotiating parties for the major awards were
the Retail and Wholesale Merchants Association and the distribution unions.

After the Employment Contracts Act and the expiry of the Grocery and Supermarket Award, the main change in the bargaining structure, as in other sectors, was the elimination of industry-wide documents which were replaced either by enterprise agreements or by individual employment contracts based on, or renegotiated from, the old awards. Of the new contracts, the Department of Labour had received over 80 collective employment contracts covering 20 or more employees in the retail sector as at June 1992 (Department of Labour, Contract, vol.3, July 1992). These contracts covered 11,249 of the 140,000 persons engaged in the retail sector (persons engaged include working proprietors who were estimated to number about 11,000 over the sector). This was certainly not the full extent of collective employment contracts in the retail sector, however. The distribution unions for their part claimed that 20,000 were covered in union negotiated contracts alone.

\section{Union coverage}

Under the Labour Relations Act, union coverage of almost all employees in the retail sector belonged to the three distribution unions (clerical employees provide one area of exception to this coverage). The two main distribution unions were, and remained until recently, the Northern Distribution Workers Union and the New Zealand Distribution and General Northern Distribution Workers Union and the New Zealand Distribution and General
Workers Union which covered the lower North Island and most of the South Island. These Workers Union which covered the lower North Island and most of the South Island. These
two unions have now amalgamated as the National Distribution Union. Retail workers in Nelson and Marlborough are still covered by the separate Nelson Marlborough Distribution Workers Union.

It appears that actual union membership in the retail sector under the Labour Relations Act was no greater than 27 percent of eligible members and perhaps somewhat less. This figure was obtained by comparing the approximate number of employees in the sectors covered was obtained by comparing the approximate number of employees in the sectors covered
by the distribution unions (from available Quarterly Employment Survey and Household Labour Force Survey data) with union membership figures (from the Department of Labour's 1990 Handbook of Union Information). The comparison is conservative as the size of potential membership has been deliberately understated where there was any doubt about coverage and size of the occupational grouping involved. The main awards contained compulsory membership provisions but, according to the unions, these were not generally enforced. The low level of membership has been usually attributed to the large number of small sites in the industry. One could note, however, that the approximate level of membership in the sector was lower than the number of persons engaged in enterprises over 50 employees, thus indicating that the unions were unable to enlist members in a large number of medium sized retail sites as well as those employed in small enterprises.
According to union officials, membership of the distribution unions fell by 20 percent to 25 perts Act, largely as a result 25 percent in the year after the passing of the Emplin contract negotiations and of continuing of hostility from employers to distribution unions are still undoubtedly the dominant

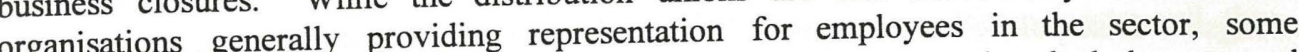
organisations gen or also emerged alternative forms of employee organistion unions; for example, staff by the end of 1992 which were separate representative committees. It was not clear, howeve, how extensive these alternative forms were or, for that matter, how dependent or independent of employer support they were. The unions claimed that they were still a strong presence in large enterprises such as supermarkets. They also appeared to have recruited some clerical members in the sector with the demise of the New Zealand Clerical Workers Union. In general, employee with the demise of the sector is probably not an attractive proposition for other bargaining representation in the agents for the same fundamentart ren wigh level of partdistribution unions, such as an
time and youth employment.

\section{Unions under the Employment Contracts Act}

The distribution unions were particularly affected by the new industrial environment of the The distribution unions therefore Employment Contracts Act in two ways: firsty, the income; and, secondly, by increased demands on their resources, pat blaty a a remployer the need to negotiate contracts at an enterprise or individual level because of employe unwillingness to negotiate at a multi-employer or industry level. The reduction in members und income forced the unions to reduce staff, for example in specialist areas such as trad and income for overall workload had increased markedly. In addition,

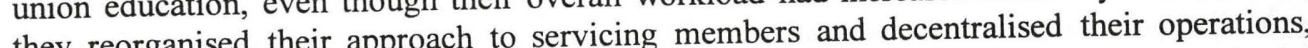
they reorganised their approan services through site placing greater emphasis on channelling resources for provision of
delegates rather than providing all services from a centralised point.

The unions' specific approach to bargaining also changed. The unions accepted that bargaining under the Employment Contracts Act had to be enterprise based, and their bargaining act focused on bargaining bargaining stres with new collective three groups based on the size and recetivent KMart was one of the initial targets. The unions saw the comparative newcomer to the New Zealand retailing industry, as unencumbered by preset position relating back to previous bargaining rounds, and therefore offering the prospect of relatively open negotiations. Secondary targets included Woolworths, Deka, and Foodtown, which had a union presence and in-house industrial relations expertise. The third level generally had a unights and Hallensteins, which employed relatively comprised chain stors, such as but were sizeable numbers of employees but were charactersed by a salion to bargaining conditions not been geared up for dealing with unions, particularly in relation to bargaining conditions of employment. In general, bargaining and other services were provided to members employed by companies other than the 49 targeted enterprises on request and as resources allowed. 
The unions' policies were clearly adjustments to the end of the award structure following
the Employment Contracts Act. They also reflected limited resources which

Alongside these policies, the unions had a number of current formal bargaining objectives. These were to increase pay and improve sick, holiday, and service leave provisions, demands on penal rates by protecting weekly earnings, especially for new provisions, me securing union rights, for example to site meetings and direct access to Maintaining conditions for new employees was new employees were not exploited but also to peen as important, not only to ensure that employees from being und ox existing and input into traing initing EEO development of of both the unions and the Retail and Wholesale Merchants Association was that the view mployers such as Countdown, Kirkcaldies, and Woolworths were was only a fe training programs for staff.

Although the unions' bargaining objectives were clear, it was also evident from speaking with union officials that they recognised that they were not able to dictate bargaining positions to their members, and that they were prepared to accept significant moveming way from these objectives, such as different conditions for new employees, where site members required it.

In general, neither the distribution unions nor their members in the retail sector had a reputation for industrial militancy. The reasons for this are probably simple, i.e. low unionisation and a widely dispersed low-skilled workforce, which meant little real bargaining power, especially in times of high unemployment. In the first half of 1992 however, the Northern Distribution Union began carrying out an American-style of 1992 , made" campaign in Auckland which primarily involved identifyin American-style "unionwhat it regarded as anti-union practices of certain enterprises negotiate collective employment contracts. The primerprises, particularly the refusal to picket established by distribution union officias the prime example of this activity was the distributed lists of enterprisution union officials at Pak'n Save in Auckland. The union also collective che thereby encouraging shops without union contracts to deal with the union.

\section{Employers}

For retail employers, the main bargaining agent and coordinator of industry wide policie (for example, industry promotions) prior to the Employment Contracts Act wide policies and Wholesale Merchants Act was the Retail role became much

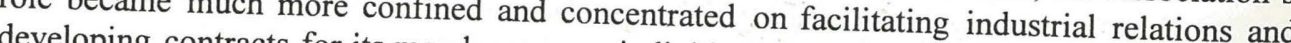
entered the bargaining arena, either providing ividual enterprise basis. Other organisations activity or directly representing rataing profile in the area were Wheeler Camployers. Two organisations which established were probably determinis were probably determining their own bargaining strategies with only minimol outside direction.
In a sector comprising over 26,000 enterprises covering a wide range of retailing activity, including stores as distinct as small boutiques and supermarket chains, and without effective central industrial organisation, employer bargaining strategies obviously varied after the introduction of the Employment Contracts Act and produced a range of different outcomes. Common underlying concerns, however, were the reduction of labour costs and the achievement of increased flexibility.

\section{Outcomes of bargaining}

Substantial change occurred in some areas. For others there was little or no change apart from the automatic deeming of award provisions into individual employment contracts as provided under the Employment Contracts Act. One well documented case where there was considerable change was the negotiation of employment contracts by Whitcoulls to fit with its overall corporate strategy. According to Whitcoulls, the contracts, which were essentially identical individual employment contracts apart from some personal details such as pay, were, in the jargon of today, designed to move the company "towards the reality of an empowered front-line workforce, and thus raising levels of customer service" (Handley, 1992).

The contracts were formulated by a committee, selected by the company, which dealt directly with staff. Union involvement was minimal (deliberately minimised by the employer in the union's view). The specific issues dealt with in negotiating the contracts included: integration of company values into the contracts and work; job reclassification and simplification of job structures; performance appraisal and pay; a sharp narrowing of wage differentials based on age and school qualifications for young workers and those over 20 ; removal of penal rates; changes and extensions in leave provisions; extension of misconduct provisions and in-house personal grievance and dispute procedures; and the introduction of a flexible 40 hour week.

Another example of significant change was the KMart employment contract. Although less sweeping than Whitcoulls new broom approach, the KMart negotiations still produced a major shift away from age related pay, with youth rates being lifted by between 22 percent and 28 percent. Other changes in the composition of remuneration such as the reduction of penal rates and new shift arrangements to enhance working hours flexibility were also introduced. In addition, the unions and KMart also agreed to keep a formal role for the union and union delegates on site, including ensuring new employees were given the opportunity to join the union and provision for union education leave for delegates. The employment contract negotiated with the booksellers, Bennetts, was seen as another progressive contract by the unions with special attention being given to training and skills recognition.

Looking more generally at the level of specific types of change in terms of bargaining outcomes that were occurring in the industry up to the end of 1992, the main movements appeared to be the reduction or elimination of penal rates, changes in hours, the removal of allowances, and increases in standard rates. In addition to these changes, the unions believed that leave, for example sick leave, was also being reduced to the level of the minimum code in some contracts. 
Rates of pay

The clearest overall adjustment was the elimination of penal rates. As illustrated in the following graph, from 1991 to 1993 there has been a nearly 40 percent reduction in hours paid as overtime and a clear increase in hours paid as ordinary time. It is noted that indicates only the elimination of penal rates, not the incidence of reduced penal rates.

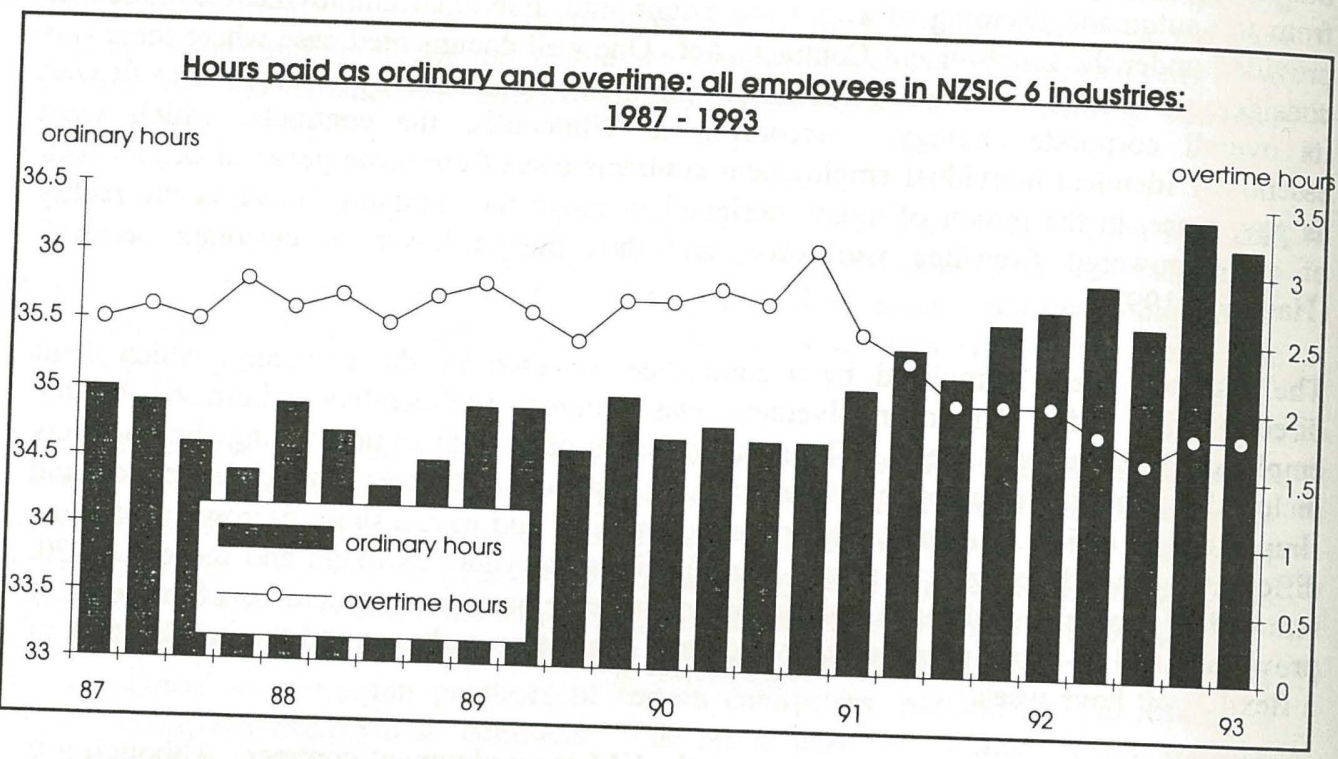

There were also increases in standard rates, though it is not fully clear that they compensated for diminished penal provisions. Superficially, the average earnings data of the Employment Contracts 2.5 percent over the first three quarters after the introduction appears to strongly in other allowances) hed penal rates (and other allowances) had occurred overall. At the same time, however, average hours worked in the sectors increased by 1.4 percent. Some of this increase in hours work hours worked been paid at time and a half or double time before penal rates were adjusted would have 1.4 percent represents the minimum rise in remuneration for we adjusted and therefore which would have been expected under pre-adjustment for the increase in hours worked
Another factor to be taken into account is that movement in average earnings can also be influenced by changes in the structure of the workforce, for example, a change in the proportions of low and high paid employees in an industry where predominantly low paid employees have lost jobs. Such changes could lead to an increase in average earnings regardless of actual cost of living wage increases or adjustments to compensate for changes to penal rates to employees. Whilst available data was insufficient to indicate whether such to penal rates to employees. Whilst available data was insufficient to indicate whether such
specific changes in the structure of the workforce were occurring, the number of persons engaged in the retail sector did fall by over 5,000 from 1990 to 1991. Later data also showed that the level of jobs in the broader NZSIC 6 workforce had fallen for each of the years to the August and November 1991 quarters, and the February 1992 quarters.

The overall impact of standard pay, penal rate, and allowance adjustments on remuneration, or for that matter on the labour costs of retailers, is therefore uncertain. Clearly, however, there had been some general advances in terms of flexibility for retailers, particularly in their ability to deploy staff over wider ranges of hours without penal rate disincentives.

\section{The enterprise survey}

\section{Enterprises and their workforces}

Fifty-eight enterprises in Ashburton, Wanganui and Wellington were surveyed by personal interview in the period February to April 1992. In general, the retailers covered in the survey were small enterprises, typical of those who employ the majority of the workforce in this sector. Most of the retailers surveyed in both Ashburton and Wanganui were independent single outlets, all of which had fewer than 20 employees. More than half the independent single outlets, all of which had fewer than 20 employees. More than half the
Wanganui retailers had less than four staff. In Wellington, just under half the interviewed retailers belonged to chains of medium to small outlets, and another fifth were medium or small independents. Four department stores, three multi-activity enterprises including retailing, and two outlets operated by Trusts were also included in the Wellington survey. Sizes in Wellington ranged from less than four employees (seven stores) to more than 50 (12 stores).

The surveyed outlets were fairly evenly distributed across the three sectors, bookseller/ stationers, fashion retailers and appliance stores (the latter including some servicing outlets, second-hand dealers and local energy suppliers with retail arms).

Women made up the vast majority of employees: 70 percent in Wanganui, 75 percent in Ashburton and 79 percent in Wellington. It is interesting, though, that in Wellington the main employers of women were the larger stores - three of them employed 85 percent to 90 percent female employees, while the average for Wellington excluding the four largest firms was 58 percent. Most staff of bookshops and women's fashion shops were women while overall more of those in appliance stores were men, although in Ashburton women outnumbered men even there. Although the survey did not establish the earnings level or proportions of part-time workers among women, the predominance of male staff in appliance stores which tended to have higher minimum and maximum pates than the other stores is consistent with the overall finding that women occupy the lower paid positions in this sector. 


\section{Janet Hector, Jon Henning, Mary Hubble}

Despite the perception that young people are widely employed in retailing, this was not generally true in the surveyed sectors. With the exception of one large Wellington store, where 40 percent of the staff were under 20 , there were small proportions of young people - very few in Ashburton, 14 percent in Wanganui and 20 percent (including the large store noted above) in Wellington. This may reflect the type of stores involved: the appliance stores had fewer young people than the booksellers and fashion stores, and it appears that more young people are employed in supermarkets and large stores where skill and experience are less valued. There was no evidence of substitution of younger for older workers, and this is consistent with the comments of some employers, particularly in small shops, that they valued experience in their employees. On the same basis, the lower proportion of young people in appliance stores may reflect the fact that appliance stores provide more training in product knowledge than the other groups.

Ethnically, Europeans predominated, exclusively in both smaller centres, while in Wellington there were some Pacific Island and Asian people but very few Maori.

\section{Business pressures and responses}

Generally in our respondents' opinions 1990 and 1991 had been a hard couple of years for retail; many respondents commented on the decline in consumer spending which, as noted earlier, affected the whole retail sector. This was accentuated by increased competition, including (in Wanganui and, to a lesser extent, Wellington) the introduction of K-Mart and mall development. By the time of the interviews, the majority of respondents reported either static or improving business, and the majority were optimistic about business prospects. There appeared to be a slightly greater proportion of declining businesses in the two regional centres, though the non-participation rate by respondents in Wellington could two regional centres, thoug

The response of the surveyed businesses to these tough conditions varied, though most focused on reduction of labour costs. This was generally achieved by reducing staff numbers especially in the North Island, and secondly by changing pay rates, as is discussed in more detail below. Businesses also mentioned tighter control of overheads and alteration or better management of stock.

\section{Bargaining}

In this environment, it might be expected that there would be some interest in taking advantage of the Employment Contracts Act to negotiate reduced labour costs, particularly given the additional pressures of extended opening hours affecting some retailers. In fact, awareness of the content of the Act varied. Most of the employers interviewed recognised the opportunity available to them under the Act to propose new forms of contracts and new or altered contract provisions, but a number had not yet taken up the opportunity. There were a very few instances of employers who appeared to believe the award system still existed; these employers had very few staff and had not usually employed new staff recently.
In a sense, although the award had collapsed, many of the employers surveyed had changed In a sense, although the anterprises interviewed had little in their bargaining practices. A good proportimply translated into individual contracts retained the framework of the old award, often simply translated into ind adjusted aspects by the deeming provision of the Employment Contracts Act. Some had adjusted aspects of these individual contracts. There were few genuinely new contracts appeared to be the more in Ashburton and significantly more in Wellington. It generally appeared to be the more in Ashburton and/or those opening for significantly longer hours who had thoroughly larger employers and/or those opening employers rather than employees, in virtually all revies, who had initiated negotiations in the past year.

Co representatives on either side even where new contracts or There was little involvement of representatives on either side even workplaces of under eight a significant change to the award had been negotiated. In wher employees, most discussions had taken place at an individual level rather than with groups. Employers generally did not use representatives, with the excepton of two Wellington Emplocilly from accountants or other retailers in the employers. Some sought an regional centres, and sometir employers commented

The ther side of the Union There was little evidence of a strong union role on the other side of the acknowledged representation occurred only in large collective contracts, bearing out the acknowledged union strategy, noted above, of focusing on large employers as a result of lack of resources for enterprise based bargaining. Not all employers were aware of the union membership for enterprise based bargat he or after the Act. Some reported that their emploes had of their employees, either before or after the Act. Some loptanding low servicing profile resigned from the union, in some cases because of the longstaned either, except in two of the unions. Alternative employee organisations had not enkip and promoted in-house of the unions. Alloyers actively discouraged union membership and promoted in-house organisations.

Employers varied in the extent to which they had changed their bargaining practices. Employers varied in the extent to which the contracts, while Generally it was the large organisations who had initiated a ritions to roll over and had done many smaller employers had simply allowed the award conditions to roll over and had done nothing about bargaining for themselves. Although bargaining is now the responsibility of individual employers rather than a few representatives, small employers, particularly in individual employers rather to have already had a practice of dealing with their own staff regional centres, appeared to have arrangements such as above award payments and varied working hours.

\section{Outcomes of bargaining}

Functional flexibility

Flexibility was evident within limits. As is commonly acknowledged, sales staff in smal Flexibility was evident within limits. As is colities, including not only customer service, bu enterprises tend to have a range of respons and display or "merchandising". These tasks require 
a relatively low level of skill, although maturity and experience were valued in at least some staff, as noted above. In general, the sales staff did not share the more specialised fields of accounts or buying, which were the responsibility of the manager or specialised staff. This has implications in relation to training and career development. On-job and informal training was generally considered appropriate for sales staff, especially where there were fewer than five staff. More formal training was provided, often by outside agencies, for special functions such as Lotto or Instant Kiwi and in appliance stores. In a few cases, rearly a third of the businesses werc nearly a third of the businesses were considering introducing some new method or technology (generally point-of-sale computerisation), this was not expected to change work content or require significant training. Overall, the general picture is one of a segmented workforce with few opportunities for advancement, especially in small firms.

\section{Hours and flexibility}

Long established flexibility was also evident in the approach to staffing the wide range of opening hours apparent among the surveyed businesses. Opening hours showed a variety which may be evidence of different rates of change - a combination of a response to economic pressures and to the changes over recent years in the Shop Trading Hours legislation. Friday night and Saturday morning trading prevailed in Ashburton and to a large extent in Wanganui, although the late night option there (not always Friday) appeared to be declining. In Wellington about half the stores followed this pattern. A quarter had dropped the late night but opened on Saturday, and three stores opened on Sunday. The total weekly opening hours ranged from 41.5 to 68.5 .

Coverage of these hours was generally achieved by a combination of full and part-time staff, usually on a roster system, as might be expected. The proportions of part-timers in the various sectors appeared to reflect both the higher than average proportions in the retail sector generally, and perhaps the range of hours opened in the three centres. In Ashburton, 13 percent of the workforce were part-time, employed in just under half the stores, and only one had a majority of part-timers. In Wanganui, 35 percent were part-time, spread over 75 percent of stores and almost two thirds had a majority or exclusively part-timers. In Wellington, the figures were higher again: 39 percent of the workforce were part-timers, employed in 86 percent of stores, and 45 percent had a majority of part-timers. These figures do not imply that part-timers were necessarily used to cover the extended hours it is no doubt useful to employ part-timers to cover the busy hours during the day as well. This is consistent with the fact that these arrangements were not new: flexible staffing arrangements certainly preceded the Employment Contracts Act.

Only a limited amount of casual employment was apparent, using school children at Christmas in particular (mainly in booksellers/stationers), and in some cases a "pool" of people (eg former employees) able to cover absences or particular demand such as school holidays. Given the value placed on experience, this traditional pattern makes sense.
Pay rates and structures

The area in which flexibility has been sought by employers across the economy since the Employment Contracts Act is pay rates. Here the surveyed firms showed some changes to existing patterns. The changes most often involved reducing or eliminating penal rates with some compensatory rise in ordinary rates, though in most contracts some form of penal or overtime rate was retained.

However, there was still continuity in pay structures. Most employers stated that pay differentials were related to experience (length of service) and responsibility. Those with young employees generally had youth rates, starting at lower than adult rates but in some young employees generally had youth rates, starting at lower than adult rates but in some
cases catching up relatively quickly. These patterns broadly reflected the structure of the award, which based pay rates on age, length of service, type of work and responsibility for supervision.

Businesses varied widely in the extent to which they had changed conditions: some had changed nothing since the expiry of the award, while others had made considerable adjustments. A good proportion of the enterprises interviewed had retained the framework adjustments. A good proportion of the enterprises interviewed had retained the framework
of the old award(s), whether translated unaltered into individual contracts by the deeming provision of the Employment Contracts Act, or with some adjustment to rates of pay and penal rates. Most change had occurred in Wellington, and it was generally Wellington employers who indicated an intention to continue or to initiate adjustments to penal rates and allowances.

\section{Conclusion}

The retail sector has been subject to considerable economic pressure as a result of deregulation. Increased competition from imports and foreign entrants, together with the combined effects of changes to the Shop Trading Hours legislation and social pressures to open longer hours, in an environment of low levels of consumer spending, have generated considerable pressure to reduce costs. For some retailers this is a matter of survival, for others a question of competing for a share in a stagnant market.

These pressures have existed for some years. The introduction of the Employment Contracts Act has been something of a catalyst for change, its major direct effect being the move to enterprise based bargaining structures. Not all retail employers have taken the opportunity to initiate bargaining, and many have continued to rely on the old form of the award. Amongst those employers, little change has occurred. However, the change has created the opportunity for employers to pursue the objectives which they were unable to achieve under the award system, in particular the reduction of penal rates in order to reduce the costs of extended opening hours.

By giving individual employers the responsibility for bargaining, the Act has eliminated the need for employers to agree on a particular approach to penal rates, which was holding up change under the previous legislation. Many have used this opportunity to increase their flexibility to employ staff across a wider range of hours without incurring penal rates, 
though this has often been at least partially compensated by increased basic rates. This has been the main outcome for employers, but there have been a number of other responses too As in other sectors, there have been contracts involving simplified job structures, a focus on company values, reduction of youth differentials and so on. More commonly, efforts to reduce costs have included staff reductions and a reluctance to increase basic rates of pay.

The changed bargaining structure has also affected unions and employees. By abolishing the awards which were effectively the only channel by which the unions influenced many small employers and their employees, the influence of unions among small employers has small employers and their employees, the influence of unions among small employers has
effectively been removed. This was apparent in the surveyed sector, where the only contact effectively been removed. This was apparent in the surveyed sector, where the only contact
with unions was in a few large firms, and several employers reported that their employees had resigned from the union. Overall, the unions acknowledge a loss of membership and an inability to service employees in small businesses.

Union policies in this environment have been to concentrate their reduced resources on larger firms where they can best achieve their bargaining objectives of maintaining conditions for the largest numbers of workers. They have recognised, however, that their approach must be influenced by their members, and have accepted contracts which move away from some of these objectives where members require it.

Overall, deregulation in the context of a difficult economic environment has resulted in a che which has enabled some increase in impetus for change has been primarily in the hands of employers, who have been largely able to dictate the outcomes of bargaining.

There was no evidence in the survey of any increase in training. The union confirmed that most training in the retail sector continued to be on-job and informal, with the exception of some large enterprises and firms such as appliance retailers where product knowledge is provided by suppliers.

The question of equity was also addressed by the study. The union has claimed that conditions in the retail sector have deteriorated since the implementation of the Employmen Contracts Act. The overall evidence was mixed. Rates of pay had generally remained around the level of the award except for the off-setting of losses of penal rates and allowances in some parts of the sector. The earnings gap between NZSIC 6 and the average over all sectors appeared to be well entrenched. The employer organisations recognised that some changes had taken place but took the view that they were necessary to contain the costs imposed by the rigid provisions of the old awards. Not all the changes can be attributed to the effect of the Employment Contracts Act. Overall, however, it can probably be said that conditions had deteriorated for some workers in some parts of a sector in which a significant proportion of workers, particularly women, were already low-paid low-skilled and lacking in opportunities for career development.

\section{References}

Boxall, P. (1993), Management Strategy and the Employment Contracts Act 1991. In Harbridge, R. (ed.), Employment Contracts: New Zealand Experiences, Wellington, Victoria University Press.

Brosnan, P. (1991), Labour Market Flexibility and the Quality of Work: a Case Study of the Retail Industry, New Zealand Journal of Industrial Relations, 16(1): 13-36.

Department of Labour (July 1992), Contract, vol. 3.

Hammond, S. and Harbridge, R. (1993), The Impact of the Employment Contracts Act on Women at Work, New Zealand Journal of Industrial Relations, 18(1): 15-30.

Handley, C. (1992), Negotiating Contracts Benefiting Both Parties, paper presented to 1992 New Zealand Industrial Relations Conference, Auckland.

Harbridge, R. (1993), Collective Employment Contracts: a Content Analysis. In Harbridge, R. (ed), Employment Contracts: New Zealand Experiences, Wellington, Victoria University Press.

Heylen Research Centre and Teesdale Meuli \& Co. (October 1992), A Survey of Labour Market Adjustment under the Employment Contracts Act, prepared for the Department of Labour.

McAndrew, I. (1993), The Process of Developing Employment Contracts. In Harbridge, R (ed.), Employment Contracts: New Zealand Experiences, Wellington, Victoria University Press. 